\title{
REVIEW
}

\section{Out of Africa}

\author{
Gregory A Petsko*
}

Has anyone else wondered if those Nigerian con-artists have emigrated en masse to China, where they are now in the business of organizing scientific conferences? You know, the people who used to deluge our inboxes with promises of vast fortunes if we would only send a somewhat smaller fortune to (a) the family of some deposed or dead dictator; (b) their mother; (c) your mother; or (d) someone who would marry you, sight unseen?

I must get 5-10 e-mails a week from organizations I've never heard of inviting me to speak, chair a session, or check coats at a conference in somewhere in China I've never heard of. Occasionally, the topic of the conference is also something I've never heard of. Even when it isn't, it's nearly always a topic I have never worked on, and know nothing about. I've been invited to speak at meetings on nanotechnology, nuclear physics, kidney diseases, and trans-uranium elements. I've been invited to chair sessions on the economics of trade, global warming, and pregnancy tests. None of the invitations has promised to cover my expenses - if they had, I might have accepted the invitation to the nuclear physics meeting.

I've thought a lot about the reason for this blitz, with its apparent disregard for any relationship between the qualifications of the invitee and the subject of the meeting, and I've concluded that the Chinese government, to encourage the visibility of China as a scientific power, must make buckets of money available to conference organizers if they can show that they have lined up a certain number of international speakers, whether those speakers fit in with the conference theme or not. Some day I'm going to check this theory out, although I fear doing so may lead to my being the plenary lecturer at a meeting in Outer Mongolia on the worldwide epidemic of housemaid's knee.

I once saw a sign that said: 'Two-thirds of the world's billionaires made their money from scratch.' That's pretty impressive, I guess (although it also means than onethird, a pretty hefty percentage, made their money the

*Correspondence: petsko@brandeis.edu

Rosenstiel Basic Medical Sciences Research Center, Brandeis University, Waltham, MA 02454-9110, USA old-fashioned way, that is, by either inheriting it or marrying it), but it did get me wondering if one of the ways you could make a fortune from scratch would be by running one of those Nigerian scams, or organizing a Chinese conference. And that in turn got me wondering what slightly nefarious ways there might be to make a fortune in science. It used to be that starting a biotech company was a fairly reliable way to do it, but that was back in the days when venture capitalists were queuing up to throw their money at anyone with a life-sciences degree and a half-baked idea. It hasn't been like that for some time, unfortunately. Now you not only need a good idea, you need angel investors to tide you over until you prove your idea actually might be worth something. How unfair is that?

Still, the history of the biotech bubble suggests that one indicator of a sure-fire money-making scheme might be the sudden explosion of people doing it. If that's true, then candidates for get-rich-quick scientific schemes aren't hard to find. However, because some of the things that lots of people are doing that make a lot of money, like selling cell phones, may actually be above board (mostly), we need some additional criteria to distinguish consumer fads from Nigerian-style frauds. I suggest that, to be included in our list, a scheme should: (1) require no qualifications or skills of any kind to carry out (except, of course, having a larcenous heart); (2) have little or no redeeming social, scientific, or moral value; (3) make buckets of money for its perpetrators with essentially no work required; and (4) hang around for a lot longer than should be needed for anyone even slightly streetwise to realize its bogus nature. When these are taken into account, I think the following stand out.

\section{Start a (non-open-access) journal}

Anyone who has ever dealt with for-profit journals will realize that most publishers are in it for the money. And clearly the money must be pretty good, because new scientific journals keep getting started at a rate that makes the growth of weeds seem positively sluggish by comparison. It's gotten so bad that, were I lucky enough to think up an entirely new field, I probably would keep it to myself so as not to spawn 20 more journals. Given what's in many of these journals, it would also be hard to top this scam for worthlessness. One hopes that the 
growth of open-access publishing will eventually give some of these greedy so-and-sos their much-deserved comeuppance, but with grants being harder to get, I worry that authors will find it impossible to keep paying the charges that keep the open-access folks in business. Of course, institutions may find it hard to keep paying the subscription prices they currently shell out so that their faculty and students can have access to the for-profit journals, so it may be that this whole racket is indeed doomed. But while it's lasted, it has been a way to coin money.

\section{Start sequencing genomes}

You're probably thinking, wait a minute, doesn't this require skill? No. It used to require skill, but not any more. All you have to do these days is get some gullible bank to stop lending money for sub-prime mortgages and lend you enough money to buy an Illumina sequencer or its equivalent, and you're in business. And it doesn't even matter what genome you sequence! Pick some obscure organism - actually, the more obscure the better and produce a sequence and people will throw money at you to do more. And best of all, you don't even need to do the hard work of figuring out what any of the genes do, or even how many there really are (see below). Believe me, sequencing genomes beats working for a living.

\section{Start doing translational research}

It doesn't matter if you've never done translational research before. It doesn't matter if you don't know how to do it (evidently, no one does, and that hasn't stopped anyone yet). It doesn't even matter if you don't really know what 'translational research' means (as far as I can tell, no one else does, either). All you have to do is announce that you are now doing translational research and riches will pour in. Strictly speaking, this one may violate my 'no work involved' rule, because you will have to write grant applications to get those riches. But if you're doing translational research, they don't have to be good grant applications, so the amount of work is really pretty minimal.

\section{Start doing bioinformatics}

This is an even better scam than genome sequencing, because the cost of entry is much lower. No expensive sequencers are required. All you need is a laptop, a highspeed internet connection, and a printer. You can do bioinformatics from the local coffee shop! (In fact, as far as I can tell, that's where most of it is done.)

\section{Find a consortium of colleagues, create some Big Science (BS) project, and call it Something-omics}

This may be the biggest scam of all. You will have to produce data, of course, but if the genome-wide association studies and the Structural Genomics Initiative and a variety of other projects are any indication, you won't have to produce data that anyone actually cares about, or that is good for anything. The more data you produce, the less likely anyone will actually use it, or even examine it carefully. It'll just find its way into some metaanalysis eventually, where its mediocrity will be camouflaged by a dozen other mediocre studies. And the real beauty of this scam is that you never have to worry about the money not rolling in, because your BS project will never be reviewed competitively against real science projects; it will only be given a special review of its own, or reviewed along with other crud like itself. In fact, you may actually get more money if you don't do well. After all, so much money was invested in your BS project in the first place that it would look really bad if it were shut down. Far better, in the minds of most science administrators, to continue to throw good money after bad, in the hope that you will eventually come up with something - anything - that is worth crowing about.

Those are my top five disreputable ways of making a fortune in science. I'm sure you can think of others. You will note, perhaps to your surprise, that writing a column is not on my list. True, it requires no qualifications or skills, is without any value whatsoever, and can, as this very column proves, go on far longer than anyone would have thought possible. But it will make you no money. You'd be far better off running a Nigerian scam, or organizing a meeting in China. Trust me.

Published: 29 June 2012

doi:10.1186/gb-2012-13-6-162

Cite this article as: Petsko GA: Out of Africa. Genome Biology 2012, 13:162. 